Article

\title{
Acetogen Communities in the Gut of Herbivores and Their Potential Role in Syngas Fermentation
}

\author{
Chunlei Yang \\ Institute of Dairy Science, MoE Key Laboratory of Molecular Animal Nutrition, College of Animal Sciences, \\ Zhejiang University, Hangzhou 310058, China; 0616552@zju.edu.cn
}

Received: 2 May 2018; Accepted: 4 June 2018; Published: 7 June 2018

\begin{abstract}
To better understand the effects of host selection on gut acetogens and their potential role in syngas fermentation, the composition and hydrogenotrophic features of acetogen populations in cow and sheep rumens, rabbit ceca, and horse feces were studied. The acetogens detected in horses and rabbits were more phylogenetically diverse than those in cows and sheep, suggesting that the host species plays an important role in shaping gut acetogen populations. Acetogen enrichments from these animals presented good capacities to use hydrogen, with acetate as the major end product. Minor propionate, butyrate, and isovalerate were also produced. During $48 \mathrm{~h}$ of incubation, acetogen enrichments from horse consumed 4.75 moles of $\mathrm{H}_{2}$ to every 1 mole of acetate-significantly lower than rabbits, cows, and sheep (5.17, 5.53, and 5.23 moles, respectively) $(p<0.05)$-and produced significantly more butyrate $(p<0.05)$. Enrichments from cows and sheep produced significantly higher amounts of propionate when compared to rabbits or horses $(p<0.05)$; enrichments from sheep produced the highest amounts of isovalerate $(p<0.05)$. These short chain fatty acids are important precursors for the synthesis of biofuel products, suggesting that gut contents of herbivores may be promising sources for harvesting functional acetogens for biofuel production.
\end{abstract}

Keywords: ruminants; monogastric herbivores; gut acetogens; community; hydrogenotrophic features

\section{Introduction}

Acetogenic bacteria are a group of obligate anaerobic bacteria that can convert two molecules of carbon dioxide $\left(\mathrm{CO}_{2}\right)$ into acetate via the Wood-Ljungdahl pathway (WLP) [1]. Acetogenesis plays an important role in the global carbon cycle, with nearly $10^{13} \mathrm{~kg}$ of acetate being formed in anaerobic habitats annually [2]. Acetogens are facultative autotrophs that can survive by oxidizing various substances, including organic ones such as pentoses, hexoses, alcohols, formic acid, and methyl groups, as well as inorganic substrates such as hydrogen $\left(\mathrm{H}_{2}\right)$ and carbon monoxide (CO) [3]. Due to their metabolic flexibility, acetogens are widely distributed in various habitats including the guts of herbivores and termites, the intestines of humans, deep subsurface samples, marine sediments, and freshwater [4]. The WLP that is naturally present in acetogens is suggested to be the most effective known pathway to convert $\mathrm{CO}_{2}$ into organic compounds; thus, autotrophic acetogens are attractive catalysts for the utilization of syngases $\left(\mathrm{CO}\right.$, or $\left.\mathrm{CO}_{2}+\mathrm{H}_{2}\right)$ to produce organic commodities such as biofuels and chemicals [5-8], which have both ecological and economic benefits.

Acetate is the main end product of acetogenesis, but many other natural products such as butyrate, butanol, 2,3-butanediol, and ethanol can also be produced [9-12]. With the technological development of metabolic engineering and gene modification, products other than acetate can also be produced under special conditions. Through the optimization of the growing conditions (regulating $\mathrm{H}_{2}$ pressure or $\mathrm{pH}$ ) or culture methods (using batch-operated stirred-tank bioreactors), A. woodii has been used for acetate production, with the maximum acetate production reaching $7.4 \mathrm{~g} \mathrm{~L}^{-1} \mathrm{~d}^{-1}$ [13]. Using genetic engineering technology, Clostridium ljungdahlii has been used for the production of 
butyrate, butanol, and acetone [14-16], and Moorella thermoacetica has been used to produce lactate [17]. However, even though acetogens are quite phylogenetically diverse, the strains that have been used for commercial production were limited because isolation of pure acetogen strains in vitro is not easy work, and full genomic information for most acetogens is still not available [18]. Until now, only Moorella thermoacetica, Acetobacterium woodii, and Clostridium ljungdahlii were the model acetogen organisms that have been studied in detail [19]. Developing new acetogen products has always been proposed.

Considering the eating habit of herbivores, vegetation is their primary food source. Fermentation of the structural carbohydrates mainly depends on the activity of gut microorganisms, which can convert the fiber to volatile fatty acid (VFA), with the production of $\mathrm{H}_{2}$ and $\mathrm{CO}_{2}$ [20]. The accumulation of $\mathrm{H}_{2}$ would inhibit the oxidation of reduced nicotinamide adenine dinucleotide (NADH), resulting in the accumulation of lactic acid and reduction of further fermentation [21]. To maintain a balanced fermentation environment, $\mathrm{H}_{2}$ utilizing microorganisms continuously account for $\mathrm{H}_{2}$ disposal in the gut. Acetogens and methanogens are both important $\mathrm{H}_{2}$ utilizing gut microorganisms, and methanogens have a greater thermodynamic advantage compared to acetogens when competing for $\mathrm{H}_{2}$ and have been proven to be the dominant $\mathrm{H}_{2}$ utilizing candidates in ruminants [22-24]. However, functional gene analysis indicated large and diverse acetogen populations exist in the rumens of bovines [25] and lambs [26]. Lower energy losses from methane production per unit of body mass were found in rabbits and horses than ruminants $[27,28]$. In spite of a much higher ratio of acetate to propionate production that was found in the rabbit cecum when compared to rumens (17.8 vs. 2.81) [29], it is likely that larger amounts of $\mathrm{H}_{2}$ were used to synthesize acetate than methane in the hindgut of monogastric herbivores. Acetogenesis is proposed to be the dominant $\mathrm{H}_{2}$ disposal method in the hindgut of monogastric herbivores [24,30], which is characterized by a more homogeneous environment with already pre-digested plant materials, high concentrations of free amino acids, lower $\mathrm{pH}$, and sometimes the lack of protozoa and fungi (protozoa has a symbiotic relationship with methanogen) [31]. Acetogens prefer readily available and easily fermentable carbohydrates [32], and acetogenesis can be stimulated through the presence of high concentrations of free amino acids [33]. Thus, acetogens that are more efficient at syngas fermentation may be more present in the monogastric herbivores such as rabbits and horses.

Developing the animal gut contents, which contain large numbers of microorganisms, for the efficient conversion of syngas to desired organic products, can greatly advance the sustainable production of biofuels and chemicals. These microorganisms may solve the problem of the increased accumulation of animal wastes and associated pollutions caused by the development of concentrated animal feeding operations (CAFOs) [34]. The knowledge of the acetogen distribution in the guts of different host species and their potential role in syngas conversion will help us to better understand the host selection process and, in the future, develop new acetogen products using animal wastes. Therefore, the composition of acetogen populations in the rumens of cows and sheep, the ceca of rabbits, and the feces of horses and their ability to convert $\mathrm{H}_{2}$ and $\mathrm{CO}_{2}$ to short chain fatty acids (SCFAs) - which serve as important precursors for the synthesis of various biofuel products such as polyvinyl acetates, ethanol, and butanol—was studied.

\section{Results}

\subsection{Comparison of the Acetogen Communities}

The deduced amino acid sequences for $a c s B$ from the horse feces, rabbit cecum, cow and sheep rumens clustered into 61, 25, 15 and 8 operational taxonomic units (OTUs), respectively. The observed OTU number, Chao1 richness estimate, and Shannon diversity index were all higher in the horse feces and the rabbit cecum than the cow and sheep rumens (Figure 1). The evenness was highest in the horse feces, where there were 30 ACS OTUs accounting for more than $1 \%$ of the ACS sequences detected in the horse (from high to low: OTU 15, 22, 17, 31, 34, 21, 24, 33, 30, 28, 41, 16, 25, 48, 49, 27, 35, 45, 23, 38, $39,20,29,32,46,50,52,26,47$, and 60). This was followed by rabbit with 17 ACS OTUs accounting for 
more than $1 \%$ of the ACS sequences detected (from high to low: OTU 75, 82, 80, 85, 33, 84, 94, 87, 79, 96, $77,81,86,89,95,97$, and 38 ), sheep with 8 OTUs accounting for more than $1 \%$ of the ACS sequences detected (from high to low: OTU 0, 98, 6, 1,3, 10, 99, and 100), and cow with 6 OTUs accounted for more than $1 \%$ ACS sequences detected (from high to low: OTU 0, 1, 6, 3, 5, and 8) (Table S1).

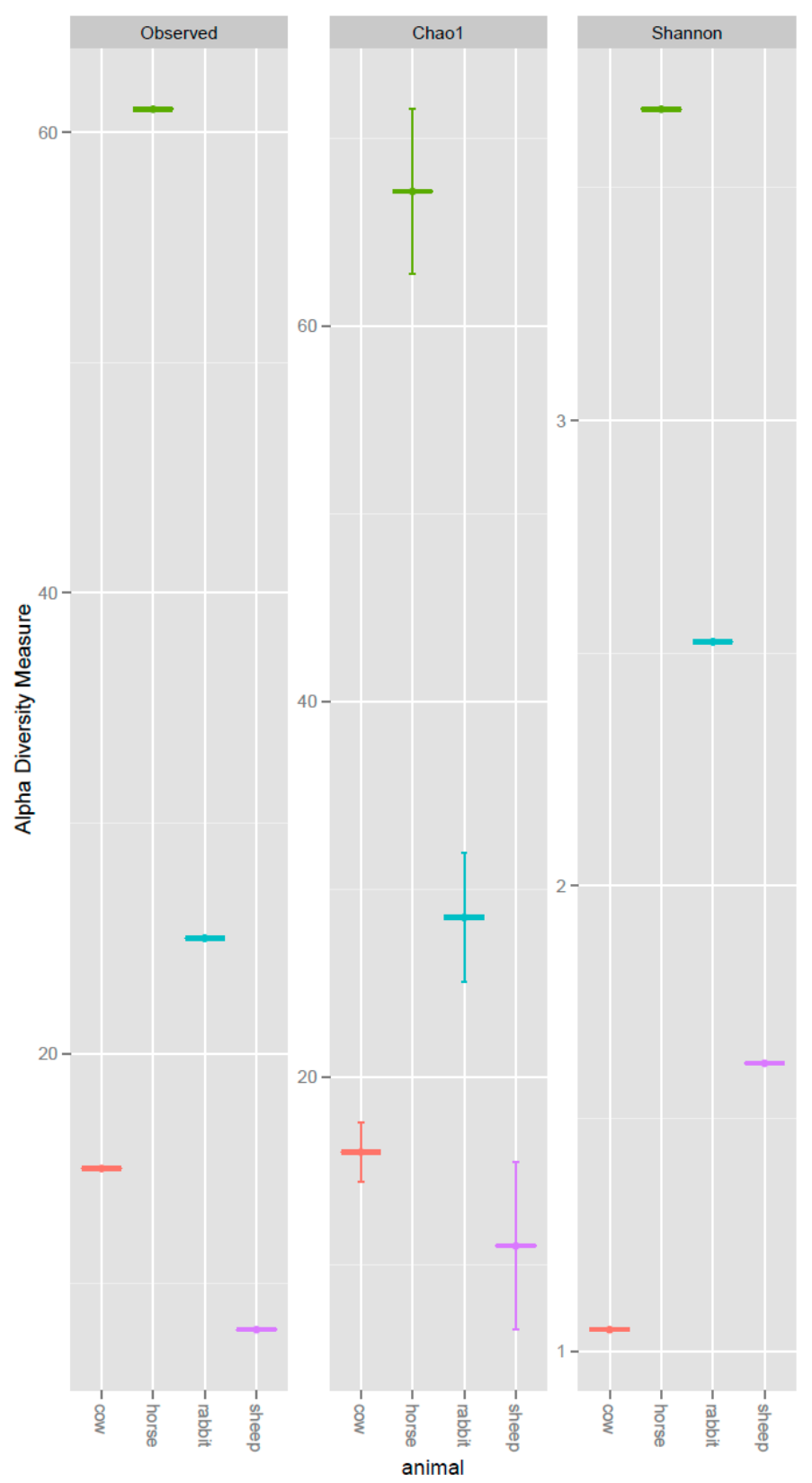

Figure 1. Alpha diversity measures of the deduced ACS amino acid sequences recovered from the rumens of cows and sheep, the ceca of rabbits, and the feces of horses. Observed = Observed OTU numbers; Chao1 = Chao estimator; Shannon $=$ Shannon diversity index.

The structure of the acetogen population was also analyzed with beta diversity measures using principal coordinates analysis (PCoA). The rumen acetogens of cow and sheep clustered separately from those of the horse feces and rabbit cecum along the PCoA1, which explained $56.5 \%$ of the total variation. The acetogen populations in the horse feces and rabbit cecum also clustered separately along the PCoA2, which explained $41.8 \%$ of total variation (Figure 2). 


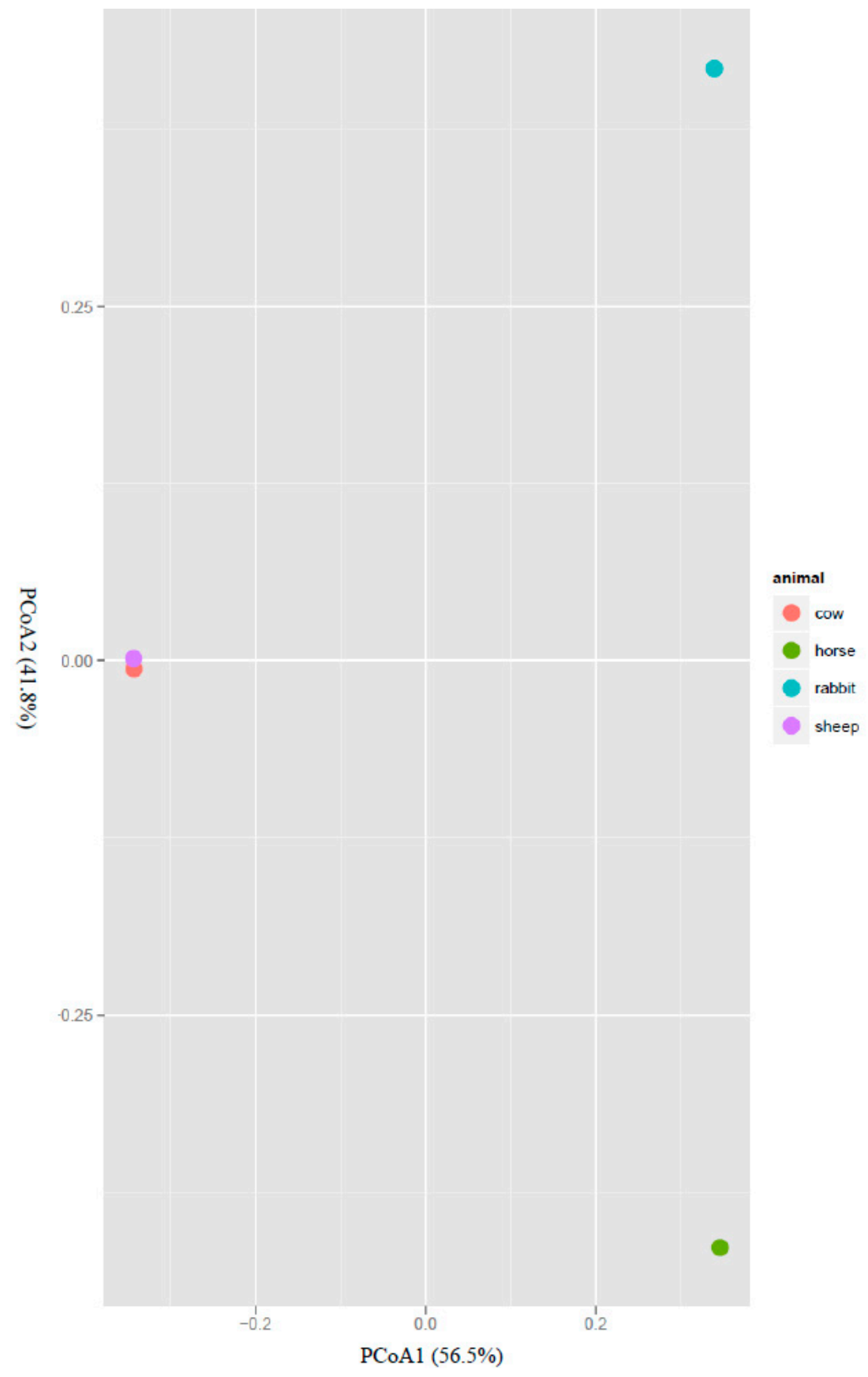

Figure 2. Covariation of the community structure of potential acetogens in the rumens of cows and sheep, the ceca of rabbits and the feces of horses using principal coordinate analysis (PCoA). The PCoA plot shows that the samples from different host species span their first two principal components, principal coordinate 1 ( $56.5 \%$ of variance) and principal coordinate 2 ( $41.8 \%$ of variance).

The between-group similarity was further analyzed using a heat map, and obvious differences were found in the ACS OTUs between the host animals. There were no shared ACS OTUs in the rumen of cow and sheep compared with the cecum of rabbit, and only 1 ACS OTU was shared between the rumen and feces of horse. Cows and sheep, both being ruminants, also showed obvious differences in acetogen communities, and even though 5 ACS OTUs were shared between cows and sheep, there were 10 unique ACS OTUs belonging to cows and 3 unique ACS OTUs belonging to sheep. When comparing the monogastric herbivores, rabbit and horse, there were only 2 shared ACS OTUs; 23 and 59 unique ACS OTUs belonged to rabbit and horse, respectively (Figure 3). 


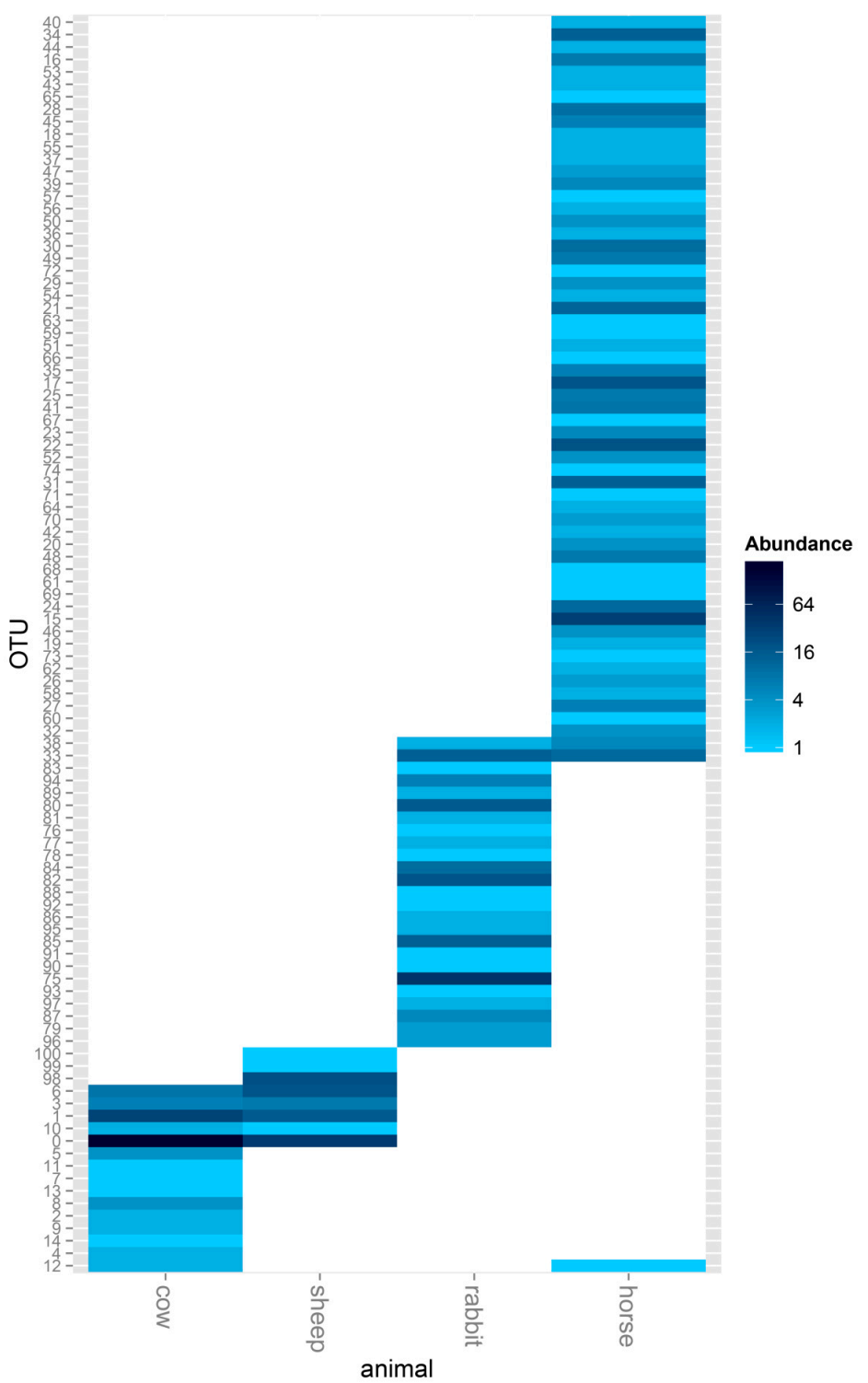

Figure 3. Assessment of differentially expressed ACS genes in the rumens of cows and sheep, the ceca of rabbits, and the feces of horses in a heat map format. A heat map showing all the ACS sequences detected in the rumens of cows and sheep, the ceca of rabbits, and feces of horses. The color scale ranges from blue (high expression) to white (low expression).

\subsection{Phylogenetic Analysis of Acetogen Communities}

All the ACS OTUs classified in the rumen of cow and sheep, cecum of rabbit, and feces of horse were included in the maximum likelihood tree (Figure 4). The acetogen populations observed across all host species were phylogenetically affiliated at 41 different places in the maximum likelihood tree. The ACS sequences detected in the rumen of cow and sheep clustered at 7 different places and were phylogenetically assigned to the Ruminococcaceae (OTU 3), Lachnospiraceae (OTU 0, 1, 12, and 9 unique cow OTUs), and Clostridiaceae (OTU 10, 1 unique cow OTUs and 3 unique sheep OTUs) families. The ACS sequences detected in the cecum of rabbit and feces of horse clustered at 11 and 26 different places, respectively, and were phylogenetically assigned to the Blautia group (OTU 33, 3 unique rabbit OTUs and 3 unique horse OTUs), Ruminococcaceae (7 unique horse OTUs), Lachnospiraceae (OTU 12, 21 unique horse OTUs and 13 unique rabbit OTUs), Clostridiaceae (OTU 38, 25 unique horse OTUs and 6 unique rabbit OTUs) and Eubacteriaceae (2 unique horse OTUs) families (Figure 4). 


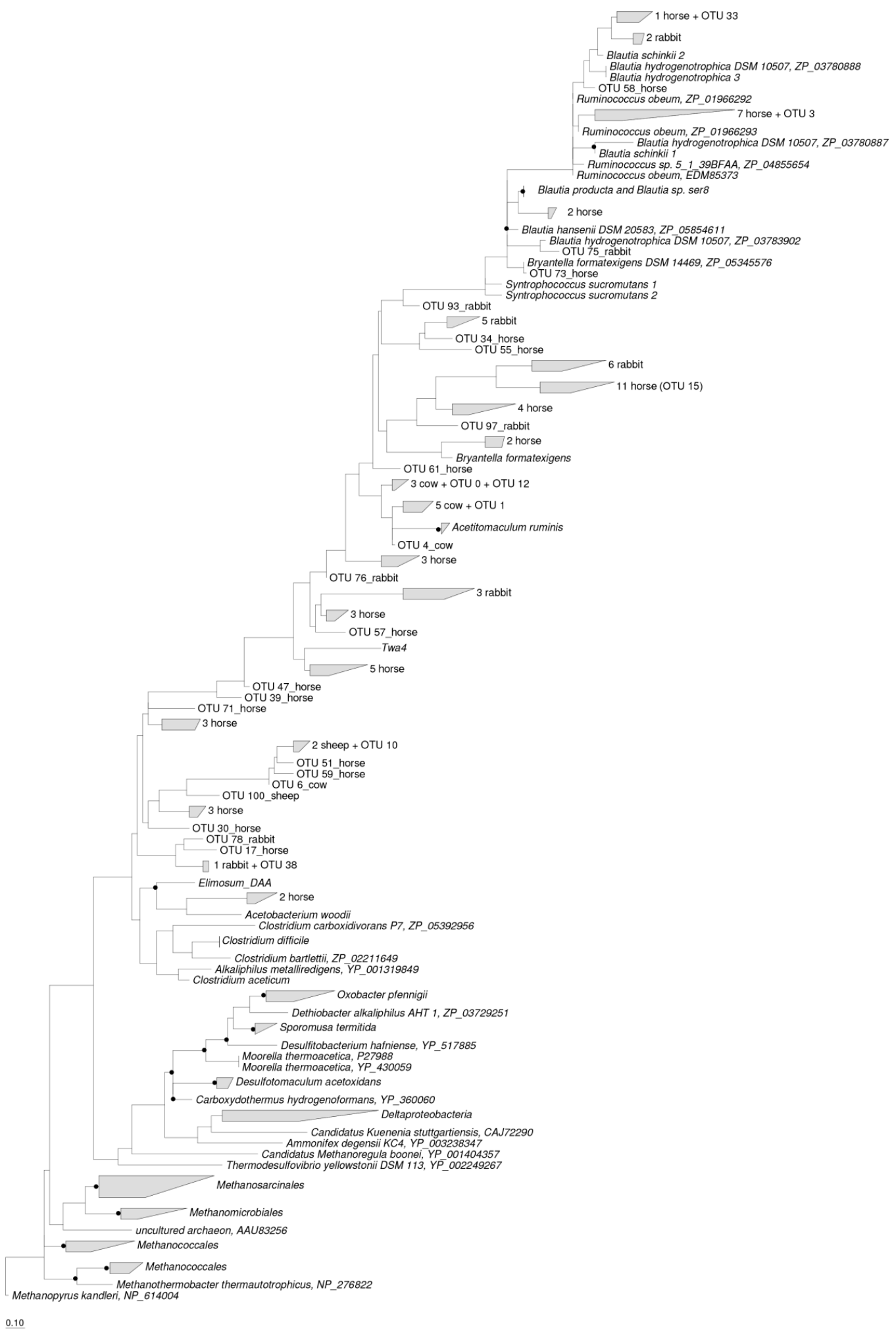

Figure 4. Phylogenetic analysis of deduced ACS amino acid sequences presented in the rumens of cows and sheep, the ceca of rabbits, and the feces of horses with reference ACS sequences (GenBank accession numbers were shown after the species names). Bootstrap values of $\geq 75 \%$ were shown at nodes as closed circles. The scale bar represents $10 \%$ sequence divergence. The number of ACS OTUs that presented in the rumens of cows and sheep, the ceca of rabbits and the feces of horses, as well as the dominant OTUs, which were indicated in brackets. 
The most abundant ACS OTU in the rumen of cows and sheep was OTU 0, which accounted for $75.58 \%$ and $35.35 \%$ of all the ACS sequences detected in the rumen of cows and sheep, respectively, and was phylogenetically affiliated with the Lachnospiraceae family, with an $85 \%$ similarity to Acetitomaculum ruminis. The most abundant ACS OTU detected in the ceca of rabbits was OTU 75 , which accounted for $27.52 \%$ of all the ACS sequences detected and was phylogenetically affiliated with the Blautia group, with an $89 \%$ similarity to Blautia hydrogenotrophica. The most abundant ACS OTU in the feces of horse was OTU 15, which accounted for $10.51 \%$ of all the ACS sequences detected and was also phylogenetically affiliated with the Blautia group, showing a $75 \%$ similarity to Blautia producta (Figure 4).

\subsection{Relative Abundances of Acetogens and Methanogens}

The relative abundance of the $m c r A$ gene that targeted methanogen populations was significantly higher $(p<0.05)$ in the rumens of cows when compared to the ceca of rabbits and feces of horses (Figure 5). The relative abundance of the fhs gene targeting acetogen populations showed no significant difference $(p>0.05)$ among all the host animals (Figure 5).
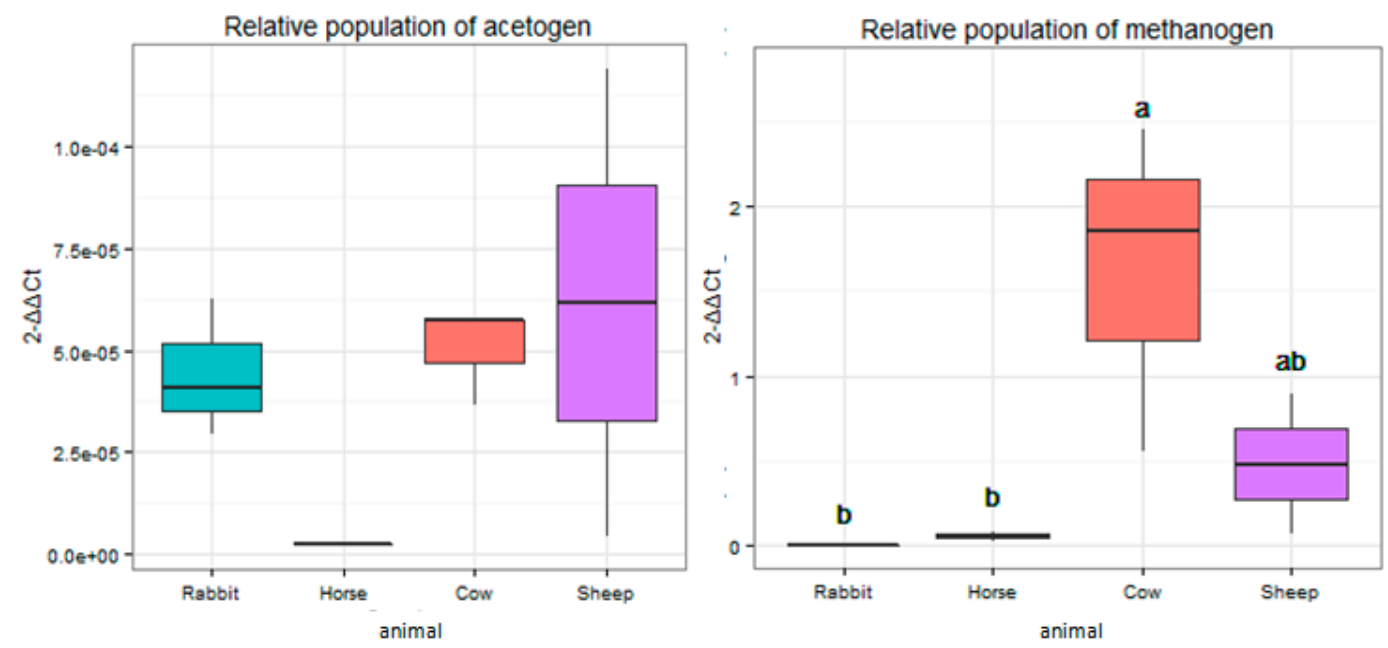

Figure 5. The relative abundance of fhs and $m c r A$ genes in the rumens of cows and sheep, the ceca of rabbits, and the feces of horses. The relative abundance was expressed as the ratio of the target gene to the $16 \mathrm{~S}$ rRNA genes in total bacteria. Groups with different superscripts means they significantly differ $(p<0.05)$.

\subsection{Hydrogenotrophic Characteristics of Gut Acetogen Enrichments}

From the growth curves of acetogen enrichments, the maximum cell densities $\left(\mathrm{OD}_{600}\right)$ were observed at $48 \mathrm{~h}$ of incubation for all the host animals studied. Acetate was the major end product, and no methane was detected (Figure 6). Minor amounts of propionate, butyrate, and isovalerate were also produced (Table 1).

During $48 \mathrm{~h}$ of incubation, acetogen enrichments from cow and sheep consumed significantly higher amounts of $\mathrm{H}_{2}$ and produced significantly higher amounts of acetate when compared to rabbit and horse $(p<0.05)$ (Figure 7). Acetogen enrichments from horses consumed 4.75 moles of $\mathrm{H}_{2}$ for 1 mole of acetate, significantly lower than rabbits, cows, and sheep (5.17, 5.53, and 5.23 moles, respectively) $(p<0.05)$ (Figure 7$)$. Acetogen enrichments from horses produced significantly more butyrate $(0.70 \mathrm{mM})$ compared to other enrichments $(p<0.05)$ (Table 1$)$. Acetogen enrichments from cows and sheep produced significantly more propionate $(0.84 \mathrm{mM}$ and $0.86 \mathrm{mM})$ when compared with rabbits and horses $(0.69 \mathrm{mM}$ and $0.71 \mathrm{mM})(p<0.05)$ (Table 1$)$. Production of isovalerate was significantly higher in acetogen enrichments from the sheep $(0.42 \mathrm{mM})(p<0.05)$ (Table 1$)$. 
Table 1. By-products synthesized during $48 \mathrm{~h}$ of incubation.

\begin{tabular}{cccc}
\hline Species & Propionate & Butyrate & Isovalerate \\
\hline Rabbit & $6.86^{\mathrm{b}}$ & $6.30^{\mathrm{c}}$ & $0^{\mathrm{d}}$ \\
Horse & $7.12^{\mathrm{b}}$ & $7.02^{\mathrm{a}}$ & $4.00^{\mathrm{b}}$ \\
Cow & $8.38^{\mathrm{a}}$ & $6.85^{\mathrm{b}}$ & $3.49^{\mathrm{c}}$ \\
Sheep & $8.59^{\mathrm{a}}$ & $6.90^{\mathrm{b}}$ & $4.17^{\mathrm{a}}$ \\
SEM & 0.075 & 0.016 & 0.016 \\
\hline
\end{tabular}

${ }^{a-d}$ Values with different superscripts in the same column differ significantly $(p<0.05)$. The data are the means.
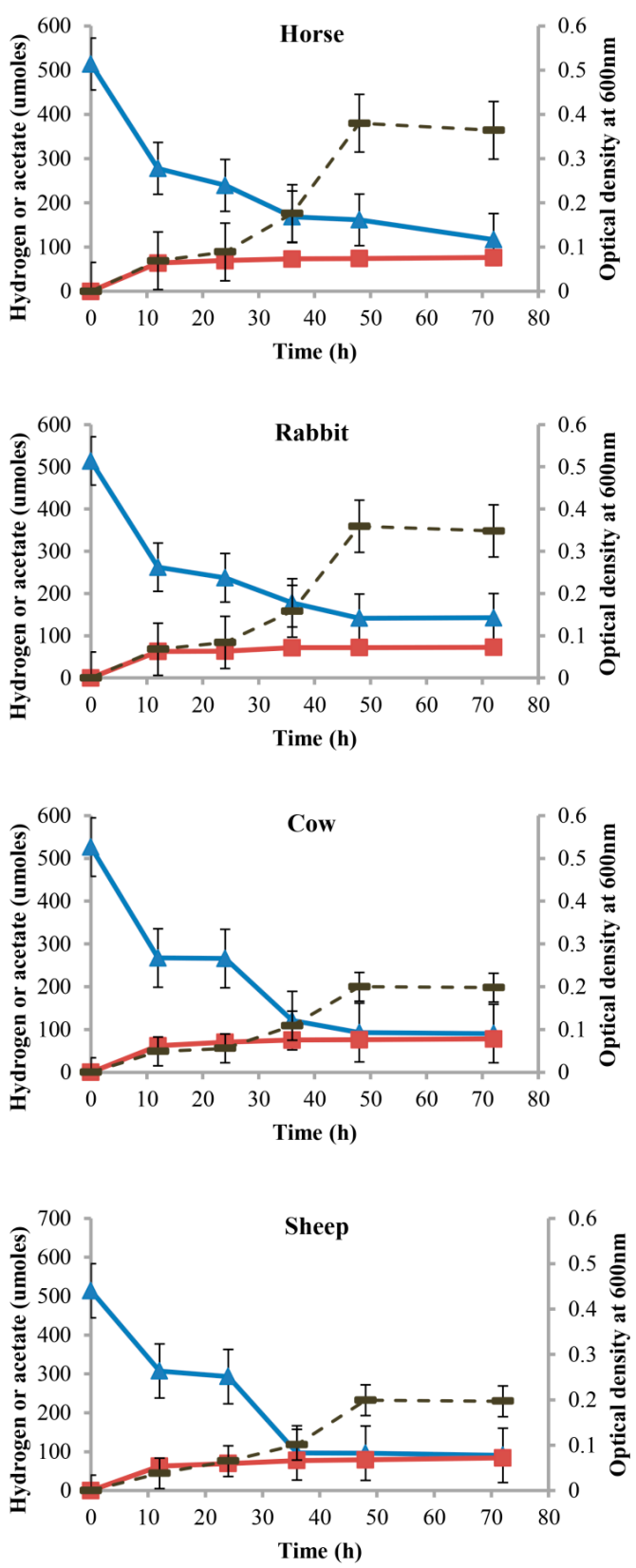

Figure 6. Acetate and hydrogen profiles of acetogen enrichment cultures from horse feces, rabbit cecum, and cow and sheep rumens under autotrophic conditions. Optical density (dashed line), acetate (squares), and hydrogen (triangles) profiles of acetogen enrichment cultures from horse feces, rabbit cecum, and cow and sheep rumens during growth on modified AC11.1 medium with only $\mathrm{H}_{2}: \mathrm{CO}_{2}$ provided as substrates. Error bars represent standard error of mean. 

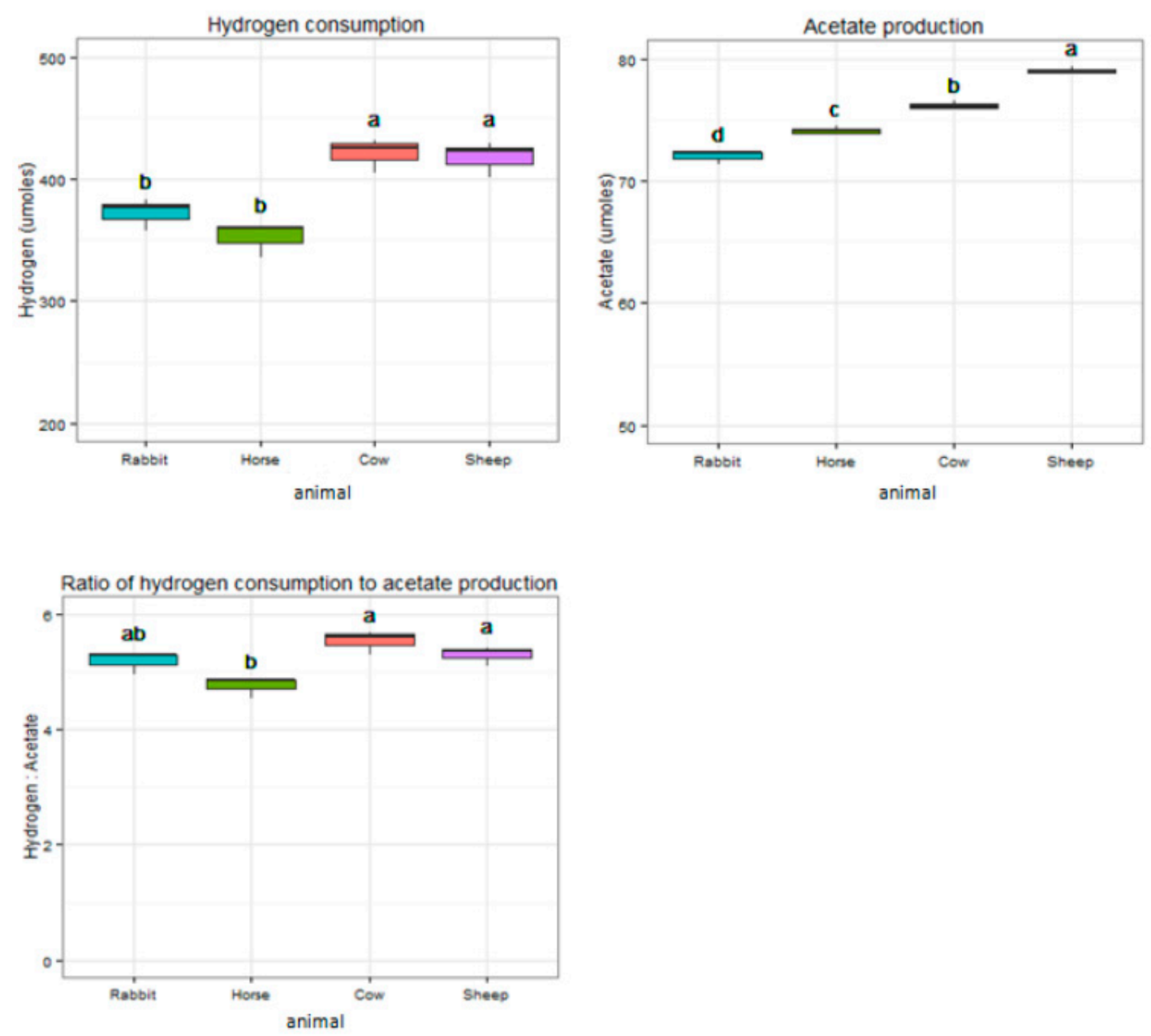

Figure 7. Different hydrogen consumption and acetate production characteristics of acetogen enrichment cultures from horse feces, rabbit cecum, and cow and sheep rumens during $48 \mathrm{~h}$ of incubation. Groups with different superscripts mean they differ significantly $(p<0.05)$.

\section{Discussion}

Due to the limited database of acetogens, most of the detected ACS amino acid sequences lack representatives [25], suggesting that many novel acetogen strains exist in horse feces, rabbit cecum, and cow and sheep rumens when compared to the published acetogen strains used in microbial production platforms. These novel $a c s B$ sequences detected can also greatly expand the database of ACS amino acid sequences for acetogens. The dominant acetogen detected in the rumen of cows and sheep was affiliated with the Lachnospiraceae family, with a high similarity to Acetitomaculum ruminis, which was first isolated from the rumen by Greening and Leedle [35]. This isolate showed a good capacity for the utilization of $\mathrm{H}_{2}$ and $\mathrm{CO}_{2}$ or $\mathrm{CO}$. The dominant acetogens in the feces of horses and the ceca of rabbits were both affiliated with the Blautia group, in which the known strains Blautia hydrogenotrophica, Blautia coccoides, and Blautia schinkii can utilize $\mathrm{H}_{2}$ and $\mathrm{CO}_{2}$ to synthesize acetate as the main product [36,37]. In addition, the minimum doubling time of Blautia product with $\mathrm{H}_{2}$ and $\mathrm{CO}_{2}$ or $\mathrm{CO}$ as substrate is only 5 or $1.5 \mathrm{~h}[38,39]$, suggesting that guts of herbivores are a promising resource for harvesting novel acetogen strains with potential industrial applications.

The true extent of acetogen biodiversity in the gut of herbivores is not known because most acetogen organisms cannot be cultured ex vivo. However, there was a clear host-specific effect on the gut acetogen community in the host animals used in our study. The higher richness (the number of different species present) and evenness (the frequencies of the different units making up a population) 
of acetogen populations in horse and rabbit compared to ruminants suggested that the monogastric herbivores own a more diverse acetogen community than ruminants, which is consistent consistent with previous reports that reductive acetogenesis is a more important hydrogen disposal method in the hindgut when compared to the rumen [24,30]. In addition, cows and sheep, as ruminants, showed a rather different acetogen community when compared to rabbits and horses, characterized by phylogenetically different distributed ACS OTUs. Because of the limited database of known acetogens, the acetogen strains distributed in the host animals studied could not be accurately classified. However, from the maximum likelihood tree that was constructed based on a previously reported tree topology of the 16S rRNA gene and the ACS amino acid sequences, the ACS sequences detected in the rabbit cecum and horse feces phylogenetically affiliated more broadly, including the Ruminococcaceae, Blautia group and Lachnospiraceae, Clostridiaceae, and Eubacteriaceae families, than the rumens of cows and sheep that mainly contained the Lachnospiraceae, Clostridiaceae, and Ruminococcaceae family. This suggests that host species or organ function may be an important driver of acetogen community composition. Similar results were obtained from the studies of bacterial communities in the cow and hoatzin, which were clustered primarily by functional environment (foreguts cluster separately from hindguts) and then by the host [40]. In previous studies on fecal bacteria, the 16S rRNA gene also revealed that the microbiota of mammals is specific and rather stable for their particular host species [41-43]. These differences at or below the family level of acetogen populations in the guts of cow, sheep, rabbit, and horse perhaps also contribute to their different hydrogenotrophy. Using the RNA stable isotope probing (RNA-SIP) techniques, previous studies indicated that the novel ACS sequences, closely related to the Blautia spp., could be associated with $\mathrm{CO}_{2}$ and $\mathrm{H}_{2}$ metabolism and may play a key role in the kangaroo foregut, in which acetogenesis is the predominant $\mathrm{H}_{2}$ disposal method with little amounts of methane produced [44]. Acetogen strains performing mixotrophic growth (using $\mathrm{H}_{2}$ and organic substrates simultaneously for growth) may be more competitive with methanogens because mixotrophic growth is energetically more favorable than methanogenesis in some situations [45]. Although the diets provided for cattle, sheep, and rabbits had a similar roughage ratio (about 55\%), the commercial diet of horses had a lower crude fiber content (about 10\%) according to the product description. The different contents of diets may also partly account for the differences in acetogen communities detected among these animals. Through analyzing the fecal microbial communities from 33 mammalian species, Muegge et al. (2011) found that diet is an important driver of the functional capacity of the gut, and can lead to a convergence of microbial communities among phylogenetically un-related hosts [46].

As gut fermenters, various microorganisms that are responsible for the efficient fiber digestion exist in the guts of cow, sheep, rabbit, and horse. Methanogens and acetogens are two important $\mathrm{H}_{2}$ disposal candidates in the guts of herbivores, which play important roles in the final stage of organic matter decay, reducing $\mathrm{CO}_{2}$ into methane or acetate, the latter providing significant energy benefits to host animals [47]. The target genes of fhs and $m c r A$ used in our study are reported to be the best targets for quantifying acetogens and methanogens currently [48-50]. Large amounts of acetogens and methanogens were observed in the rumens of cows and sheep, the ceca of rabbits, and the feces of horses in our study. The rumens of cows harbor a significantly higher abundance of methanogens than the ceca of rabbits and the feces of horses, which is consistent with previous studies showing that methanogens are the dominant hydrogen disposal organism in rumen. A higher abundance of methanogens in the rumen when compared to the cecum of rabbits and horses was also observed in the study of Abecia et al. [29] and Morvan et al. [51], respectively. No significant difference in acetogen abundance was observed among all the host animals studied, suggesting an important role for reductive acetogenesis in their gut. In the study of Morvan et al. [51], larger amounts of acetogens were detected in the cecum of horses compared to the rumen of cows and sheep. Perhaps different sampling sites, experimental methods, diets, and host animals can explain this difference. In their study, the cecal contents were used as a sample, and the horses were fed with a high forage diet (70\% hay); in addition, they used the counting method to estimate the microbial numbers. 
Even though the molecular analysis indicated the potential acetogen communities were rather different in the different host animals, the acetogen enrichments from all the gut systems presented good potent hydrogenotrophic activity that rapidly consumed exogenous $\mathrm{H}_{2}$ and $\mathrm{CO}_{2}$ with acetate as primary end product. The ratio of $\mathrm{H}_{2}$ consumption to acetate production was slightly higher than what would be expected based on the stoichiometry of the acetyl-CoA pathway of reductive acetogenesis $\left(4 \mathrm{H}_{2}+2 \mathrm{CO}_{2} \rightarrow \mathrm{CH}_{3} \mathrm{COOH}+2 \mathrm{H}_{2} \mathrm{O}\right)$, probably because some $\mathrm{H}_{2}$ and $\mathrm{CO}_{2}$ were consumed for the formation of cell carbon, new biomass, and for the synthesis of minor other end products [52]. Currently, using acetogens, especially bacteria of the genus Clostridium and Acetobacterium for chemolithoautotrophic production of acetate, is of special interest because acetate is an important bulk chemical and serves as the precursor for the production of ethanol, polyvinyl acetates, etc., which are promising and widely used biofuels. Acetobacterium woodii is the most popular acetogen organism for acetate production until now, and many studies have been conducted to improve its acetate production ability for industrial applications [13,53]. Acetobacterium woodii was first isolated from marine sediment and could consume 6 moles $\mathrm{H}_{2}$ and produce 1 mole acetate [54]. The acetogen enrichments from the rumens of cows and sheep, the ceca of rabbits, and the feces of horses in our study can consume an average of every 5.53, 5.23, 5.17, and 4.75 moles for $\mathrm{H}_{2}$ to synthesize 1 mole of acetate during the $48 \mathrm{~h}$ of incubation, respectively. This suggests that enriching potential acetogens from the gut contents of herbivores is a good, promising method in acetate production, and it is much easier to operate than isolating pure acetogen strains. Except for acetate, other SCFA products such as butyrate, propionate, and isovalerate were also produced from the acetogen enrichments in our study. Butyrate is an important precursor to produce butanol that is of great value as a biofuel [55] and is also widely used in food supplements and flavorings [56,57], as well as acts as a feedstock for the production of cellulose acetate butyrate [58]. Cellulose acetate butyrate is a thermoplastic that has various applications such as in paints [59] and polymers. Propionate is generally regarded as a safe three-carbon chemical with varieties of applications, for example, it can be used as a food preservative or herbicide because of its antimicrobial properties [60] and can be used in the manufacture of cellulose derived plastics [61]. Other forms of propionate, such as propionate salts, can be used as perfume in the cosmetics industry, and citronellyl or geranyl propionate can be used as flavor enhancers in the food industry [62]. Through modifying the growth conditions or using a genetic engineering approach, some acetogen strains have been reported to produce other dominant products rather than acetate from syngas fermentation. Acetogen organism C. ljungdahlii has been modified for the production of ethanol, butanol, 2,3-butanediol, and acetone [10,14,15]. Moorella thermoacetica has been modified to produce lactate [17], and Butyribacterium methylotrophicum can produce comparable amounts of butyrate to acetate at molar levels by modifying growth conditions [63]. In our study, during $48 \mathrm{~h}$ of growth, significantly higher amounts of propionate were produced from the acetogen enrichments of cows and sheep. The acetogen enrichments from horse feces produced significantly higher amounts of butyrate, and they also consumed the lowest amounts of $\mathrm{H}_{2}$ to produce considerable amounts of acetate. Considering the ease of sampling, developing horse feces isolates for acetate or butyrate production may be of great value. Due to the gut contents of herbivores presenting good capacity for the conversion of syngas into SCFAs, they may be good sources for harvesting functional acetogens for biofuel production. It is also a good way to treat animal wastes for both environmental and economic benefits.

\section{Materials and Methods}

\subsection{Sampling}

All the experimental protocols in this study were approved by the Animal Care Committee of Zhejiang University (Hangzhou, China), and complied with the university's guidelines for animal research. Rumen contents were collected from six ruminally fistulated lactating Chinese Holstein cattle raised in Hangzhou Zhengxing Animal Husbandry Co., Ltd., China fed with a mixed diet containing 
$28.00 \%$ alfalfa, $10.00 \%$ Chinese wild rye hay, $17.00 \%$ silage corn stalk, $27.00 \%$ corn, $5.00 \%$ wheat bran, $5.00 \%$ soybean meal, $4.00 \%$ cottonseed meal, $1.50 \%$ calcium salt, $1.00 \%$ baking soda, $0.50 \%$ salt, and $1.00 \%$ vitamin premix, and four ruminally fistulated Hu sheep aged four months raised in the experimental ranch of College of Animal Sciences, Zhejiang University, China fed with a mixed diet containing $55.00 \%$ Chinese wild rye hay, $20.25 \%$ ground corn grain, $9.00 \%$ cottonseed cake, $6.75 \%$ soybean meal, $6.75 \%$ bran, $0.90 \%$ salt, $0.45 \%$ baking soda, and $0.90 \%$ phosphor-calcium powder. Cecal contents were collected from six New Zealand White rabbits aged six months bought from the University of Chinese Medicine in Hangzhou fed with a mixed diet containing $12.00 \%$ corn, $18.00 \%$ bran, $8.00 \%$ soya bean cake, $31.00 \%$ forage meal, $10.00 \%$ malt root, $16.00 \%$ chaff, $0.80 \%$ powder, $0.50 \%$ salt, and $3.70 \%$ commercial additives, the performance of euthanasia by intravenous injection of $100 \mathrm{mg} / \mathrm{kg}$ (body weight) phenobarbital sodium (Sigma, Saint Louis, MO, USA) and removal of cecum were undertaken by a trained animal technician (license number: 15128, issued by Zhejiang University Laboratory Animal Center, Hangzhou, China). Fresh feces were collected from four Australian horses aged four years raised at Bojun Horse Club, Hangzhou, China fed with a commercial diet provided by Beijing Red Runm Technology Company, Ltd (Beijing, China). All the fresh samples from each host species were well mixed respectively, and immediately put into an anaerobic glycerol preservation solution, $100 \mu \mathrm{L}$ of Titanium III nitrilotriacetate was added to ensure an absolutely anaerobic environment. Ice boxes were used to transport the samples to the lab and saved at $-80^{\circ} \mathrm{C}$.

\subsection{Total DNA Extraction and Real-Time Quantitative PCR}

Total DNA was extracted from 0.1 grams of each of the stored samples using the cetyltrimethylammonium bromide (CTAB) method described by Gagen et al. [25]. Potential acetogens and methanogens were amplified by the primers (Table 2) targeting the genes of formyltetrahydrofolate synthetase (fhs) [48] and the methyl coenzyme-M reductase A $(m c r A)$ [49], respectively. The primers reported by Denman and McSweeney [64] were used to amplify the 16S rRNA gene from total bacteria. Real-time PCR analysis was run on the ABI 7500 (Life Technologies, Tuas Biomedical Park, Singapore) system using SYBR green as dye, and followed the cycle conditions as described before [65]. The abundance of target genes (fhs and $m c r A$ ) per gram of each sample was calculated as follows: relative quantification of target $=2^{-\Delta C t}=2^{-(\Delta C \mathrm{t} \text { target }-\Delta C \mathrm{t} \text { total bacteria })}$.

Table 2. Primers used in this study.

\begin{tabular}{cccc}
\hline Target & Forward/Reverse & Primer Sequences & Size (bp) \\
\hline \multirow{2}{*}{$16 S$ rRNA of TB } & $\mathrm{F}$ & CGGCAACGAGCGCAACCC & \multirow{2}{*}{130} \\
& $\mathrm{R}$ & CCATTGTAGCACGTGTGTAGCC & \multirow{2}{*}{250} \\
\hline \multirow{2}{*}{$f h s$} & $\mathrm{~F}$ & GTWTGGGCWAARGGYGGMGAAGG & \multirow{2}{*}{140} \\
& $\mathrm{R}$ & GTATTGDGTYTTRGCCATACA & \multirow{2}{*}{216} \\
\hline \multirow{2}{*}{$m c r A$} & $\mathrm{~F}$ & TTCGGTGGATCDCARAGRGC & \\
& $\mathrm{R}$ & GBARGTCGWAWCCGTAGAATCC & \\
\hline \multirow{2}{*}{$a c s B$} & $\mathrm{~F}$ & CTBTGYGGDGCIGTIWSMTGG & \\
& $\mathrm{R}$ & AARCAWCCRCADGADGTCATIGG &
\end{tabular}

TB: total bacteria; fhs: formyltetrahydrofolate synthetase; $m c r A$ : methyl coenzyme-M reductase A; acs B: subunit B of acetyl-CoA synthase.

\subsection{Analysis of Acetogen Community}

A partial acetyl-CoA synthase gene ( $a c s B)$ amplicon library was prepared from each of the DNA samples as described by Yang et al. [65]. Briefly, subunit B of the acetyl-CoA synthase gene (acsB) was amplified from each extracted DNA sample using the TaKaRa PCR Kit (TaKaRa, Dalian, China) with $1.0 \mathrm{ng}$ of template DNA per reaction. Amplification was performed on an ABI 9700 PCR System using the protocols as described by Gagen et al. [25]. The PCR products were separated from the primers and primer dimers by electrophoresis on a 1.5\% agarose gel and purified using the QIAquick gel extraction 
kit (QIAGEN, Shanghai, China). The amplicons were then used for the construction of a clone library using the pGEM-T Easy ${ }^{\circledR}$ vector (Promega Corporation, Madison, WI, USA) and Escherichia coli DH5 $\alpha$ competent cells (TaKaRa, Dalian, China) according to the manufacturer's instructions. In total, 265, 101, 166, and 304 clones were sequenced with the T7 primer from the cow, sheep, rabbit, and horse samples, respectively (Beijing Genomic Institute, Beijing, China). The obtained sequences that passed quality control $(258,99,149$, and 295) were aligned in Mega version 4.0 [66] to strictly select the sequences that had a length of approximately $216 \mathrm{bp}$ containing the forward and reverse primers of $a c s B$. The translate tool in ExPASy was then used to translate the nucleotide sequences into amino acid sequences in a specific open reading frame [67]. The ACS amino acid sequences obtained were aligned and length-based filtered again, finally clustered into OTUs at a limit distance of 0.035 using the CD-HIT program [68]. Additional analysis of OTUs was performed in the R packages phyloseq [69], DEseq [70], ggplot2 [71], and gplots [72]. RAxML version 7.0.3 [73] and ARB [74] were used to construct maximum-likelihood trees of the deduced ACS amino acids following methods reported by Gagen et al. [25]. The obtained ACS amino acid sequences were shown in the Supplementary Materials (ACS sequences file).

\subsection{Enrichment Culture for Potential Acetogens}

Enrichment culture medium was modified from the AC11.1 medium of Greening and Leedle [35] and contained (per L): $\mathrm{Na}_{2} \mathrm{HPO}_{4}-12 \mathrm{H}_{2} \mathrm{O} 18 \mathrm{~g}$, 2-bromoethanesulfonic acid (BES) $2 \mathrm{mM}$, minerals2 $38 \mathrm{~mL}$, minerals3 $38 \mathrm{~mL}$, trace elements $1 \mathrm{~mL}, \mathrm{NaHCO}_{3} 6 \mathrm{~g}$, yeast extract $0.5 \mathrm{~g}$, L-cysteine $\mathrm{HCl} 0.25 \mathrm{~g}$, and $1 \mathrm{~mL}$ of resazurin solution $(0.1 \%)$ as an indicator [75]; the final $\mathrm{pH}$ was adjusted to 6.8 . The medium was prepared using standard anaerobic techniques [76] and dispensed in an anaerobic chamber with an atmosphere of $95 \% \mathrm{CO}_{2}$ and $5 \% \mathrm{H}_{2}$ (COY Laboratory Products Inc., Ann Arbor, MI, USA) as $9.9 \mathrm{~mL}$ aliquots in $27 \mathrm{~mL}$ Balch tubes (Bellco, Vineland, NJ, USA), sealed with butyl rubber stoppers (Bellco), and sterilized by autoclaving at $121^{\circ} \mathrm{C}$ and $100 \mathrm{kPa}$ for $20 \mathrm{~min}$.

Approximately $0.1 \mathrm{~g}$ of rumen content from cow and sheep, cecal content from rabbit, and feces from horse was inoculated separately, pressured with $\mathrm{H}_{2}$ and $\mathrm{CO}_{2}$ at a ratio of 4:1 to $120 \mathrm{kPa}$, and then incubated horizontally at $39^{\circ} \mathrm{C}$. After 2 days of incubation, $100 \mu \mathrm{L}$ of each culture was used as inoculum into $9.9 \mathrm{~mL}$ of fresh medium and incubated as described above. Headspace gas pressures in the cultures were measured regularly using a pressure transducer connected to a computer. Gas was supplemented as necessary, and cultures were grown in this manner for 7 days to enrich the hydrogen utilizers. Then, $100 \mu \mathrm{L}$ of each culture was pooled again and transferred into fresh medium as before, and all experiments were performed in triplicate. $\mathrm{H}_{2}$ and methane in the headspace and the concentrations of short-chain fatty acids (SCFA) in the culture were determined by gas chromatography (GC-2010, Shimadzu, Kyoto, Japan) for three consecutive days after inoculation using the procedure described by Gagen et al. [77].

\subsection{Statistical Analysis}

Data for the relative abundance of the fhs and mcrA genes, moles of hydrogen consumption, and SCFA production were analyzed by one-way analysis of variance in R 3.2 with individual animals as experimental units and host species as the main effect. Tukey multiple range tests were used to do multiple comparisons means among different host species groups. Significance was declared if $p<0.05$.

\section{Conclusions}

Large and diverse acetogen populations exist in the gut of herbivores, but they are distributed differently in the ruminants compared to the monogastric herbivores. Host selection perhaps plays an important role in shaping the acetogen community. Gut acetogen enrichments showed good abilities for syngas fermentation, with the production of SCFAs, which serve as important precursors for the synthesis of various biofuel products. The gut contents or wastes of herbivores are good sources 
for developing new acetogen products. To develop animal contents or wastes for bulk biofuel and chemical production, many efforts have to be made to explore suitable fermentation conditions or methods in the future.

Supplementary Materials: Supplementary materials can be found at http://www.mdpi.com/2311-5637/4/2/ $40 /$ s1.

Funding: This research was funded by the China Postdoctoral Science Foundation, grant number 2017M612004.

Acknowledgments: The author is grateful to Stuart Denman at CSIRO, Australia, for his assistance in the data analysis of this manuscript.

Conflicts of Interest: The author declares no conflict of interest.

\section{References}

1. Drake:, H.L. Acetogenesis, acetogenic bacteria, and the acetyl-CoA “Wood/Ljungdahl” pathway: Past and current perspectives. In Acetogenesis; Springer: Boston, MA, USA, 1994.

2. Wood, $\mathrm{H}$. Life with $\mathrm{CO}$ or $\mathrm{CO}_{2}$ and $\mathrm{H}_{2}$ as a source of carbon and energy. FASEB J. 1991, 5, 156-163. [CrossRef] [PubMed]

3. Drake, H.L.; Küsel, K.; Matthies, C. Acetogenic prokaryotes. In The Prokaryotes; Dworkin, M., Falkow, S., Rosenberg, E., Eds.; Springer-Verlag: New York, NY, USA, 2006.

4. Drake, H.L.; Gößner, A.S.; Daniel, S.L. Old acetogens, new light. Ann. N. Y. Acad. Sci. 2008, 1125, 100-128. [CrossRef] [PubMed]

5. Bengelsdorf, F.R.; Straub, M.; Dürre, P. Bacterial synthesis gas (syngas) fermentation. Environ. Technol. 2013, 34, 1639-1651. [CrossRef] [PubMed]

6. Fast, A.G.; Papoutsakis, E.T. Stoichiometric and energetic analyses of non-photosynthetic $\mathrm{CO}_{2}$-fixation pathways to support synthetic biology strategies for production of fuels and chemicals. Curr. Opin. Chem. Eng. 2012, 1, 380-395. [CrossRef]

7. Henstra, A.M.; Sipma, J.; Rinzema, A.; Stams, A.J. Microbiology of synthesis gas fermentation for biofuel production. Curr. Opin. Biotechnol. 2007, 18, 200-206. [CrossRef] [PubMed]

8. Lovley, D.R.; Nevin, K.P. Electrobiocommodities: Powering microbial production of fuels and commodity chemicals from carbon dioxide with electricity. Curr. Opin. Biotechnol. 2013, 24, 385-390. [CrossRef] [PubMed]

9. Bruant, G.; Lévesque, M.J.; Peter, C.; Guiot, S.R.; Masson, L. Genomic analysis of carbon monoxide utilization and butanol production by Clostridium carboxidivorans strain P7. PLoS ONE 2010, 5. [CrossRef] [PubMed]

10. Köpke, M.; Mihalcea, C.; Liew, F.; Tizard, J.H.; Ali, M.S.; Conolly, J.J.; Al-Sinawi, B.; Simpson, S.D. 2,3-Butanediol production by acetogenic bacteria, an alternative route to chemical synthesis, using industrial waste gas. Appl. Environ. Microbiol. 2011, 77, 5467-5475. [CrossRef] [PubMed]

11. Mohammadi, M.; Najafpour, G.D.; Younesi, H.; Lahijani, P.; Uzir, M.H.; Mohamed, A.R. Bioconversion of synthesis gas to second generation biofuels: A review. Renew. Sustain. Energy Rev. 2011, 15, 4255-4273. [CrossRef]

12. Ukpong, M.N.; Atiyeh, H.K.; De Lorme, M.J.; Liu, K.; Zhu, X.; Tanner, R.S.; Wilkins, M.R.; Stevenson, B.S. Physiological response of Clostridium carboxidivorans during conversion of synthesis gas to solvents in a gas-fed bioreactor. Biotechnol. Bioeng. 2012, 109, 2720-2728. [CrossRef] [PubMed]

13. Demler, M.; Weuster-Botz, D. Reaction engineering analysis of hydrogenotrophic production of acetic acid by Acetobacterium woodii. Biotechnol. Bioeng. 2011, 108, 470-474. [CrossRef] [PubMed]

14. Banerjee, A.; Leang, C.; Ueki, T.; Nevin, K.P.; Lovley, D.R. Lactoseinducible system for metabolic engineering of Clostridium ljungdahlii. Appl. Environ. Microbiol. 2014, 80, 2410-2416. [CrossRef] [PubMed]

15. Köpke, M.; Held, C.; Hujer, S.; Liesegang, H.; Wiezer, A.; Wollherr, A.; Ehrenreich, A.; Liebl, W.; Gottschalk, G.; Dürre, P. Clostridium ljungdahlii represents a microbial production platform based on syngas. Proc. Natl. Acad. Sci. USA 2010, 107, 13087-13092. [CrossRef] [PubMed]

16. Ueki, T.; Nevin, K.P.; Woodard, T.L.; Lovley, D.R. Converting carbon dioxide to butyrate with an engineered strain of Clostridium ljungdahlii. mBio 2014, 5. [CrossRef] [PubMed] 
17. Kita, A.; Iwasaki, Y.; Sakai, S.; Okuto, S.; Takaoka, K.; Suzuki, T.; Yano, S.; Sawayama, S.; Tajima, T.; Kato, J.; et al. Development of genetic transformation and heterologous expression system in carboxydotrophic thermophilic acetogen Moorella thermoacetica. J. Biosci. Bioeng. 2013, 115, 347-352. [CrossRef] [PubMed]

18. Schiel-Bengelsdorf, B.; Dürre, P. Pathway engineering and synthetic biology using acetogens. FEBS Lett. 2012, 586, 2191-2198. [CrossRef] [PubMed]

19. Schuchmann, K.; Müller, V. Autotrophy at the thermodynamic limit of life: A model for energy conservation in acetogenic bacteria. Nat. Rev. Microbiol. 2014, 12, 809-821. [CrossRef] [PubMed]

20. Kamra, D.; Pawar, M.; Singh, B. Effect of plant secondary metabolites on rumen methanogens and methane emissions by ruminants. In Dietary Phytochemicals and Microbes; Patra, A.K., Ed.; Springer: Dordrecht, The Netherlands, 2012.

21. Wolin, M.; Miller, T.; Stewart, C. Microbe-microbe interactions. In The Rumen Microbial Ecosystem; Hobson, P.N., Stewart, C.S., Eds.; An Imprint of Chapman \& Hall: London, UK, 1997.

22. Cord-Ruwisch, R.; Seitz, H.-J.; Conrad, R. The capacity of hydrogenotrophic anaerobic bacteria to compete for traces of hydrogen depends on the redox potential of the terminal electron acceptor. Arch. Microbiol. 1988, 149, 350-357. [CrossRef]

23. Joblin, K. Ruminal acetogens and their potential to lower ruminant methane emissions. Crop. Pasture Sci. 1999, 50, 1307-1314. [CrossRef]

24. Fievez, V.; Mbanzamihigo, L.; Piattoni, F.; Demeyer, D. Evidence for reductive acetogenesis and its nutritional significance in ostrich hindgut as estimated from in vitro incubations. J. Anim. Physiol. Anim. Nutr. 2001, 85, 271-280. [CrossRef]

25. Gagen, E.J.; Denman, S.E.; Padmanabha, J.; Zadbuke, S.; Al Jassim, R.; Morrison, M.; McSweeney, C.S. Functional gene analysis suggests different acetogen populations in the bovine rumen and tammar wallaby forestomach. Appl. Environ. Microb. 2010, 7, 7785-7795. [CrossRef] [PubMed]

26. Gagen, E.J.; Mosoni, P.; Denman, S.E.; Al Jassim, R.; McSweeney, C.S.; Forano, E. Methanogen colonisation does not significantly alter acetogen diversity in lambs isolated $17 \mathrm{~h}$ after birth and raised aseptically. Microb. Ecol. 2012, 64, 628-640. [CrossRef] [PubMed]

27. Dansen, O.; Pellikaan, W.; Hendriks, W.; Dijkstra, J.; Jacobs, M.; Everts, H.; van Doorn, D. Daily methane production pattern of Welsh ponies fed a roughage diet with or without a cereal mixture. J. Anim. Sci. 2015, 93, 1916-1922. [CrossRef] [PubMed]

28. Jensen, B.B. Methanogenesis in monogastric animals. Environ. Monit. Assess. 1996, 42, 99-112. [CrossRef] [PubMed]

29. Abecia, L.; Fondevila, M.; Rodríguez-Romero, N.; Martínez, G.; Yáñez-Ruiz, D. Comparative study of fermentation and methanogen community structure in the digestive tract of goats and rabbits. J. Anim. Physiol. Anim. Nutr. 2013, 97, 80-88. [CrossRef] [PubMed]

30. Fievez, V.; Piattoni, F.; Mbanzamihigo, L.; Demeyer, D. Reductive acetogenesis in the hindgut and attempts to its induction in the rumen-a review. J. Appl. Anim. Res. 1999, 16, 1-22. [CrossRef]

31. Stevens, C.E.; Hume, I.D. Comparative Physiology of the Vertebrate Digestive System; Cambridge University Press: Cambridge, UK, 2004.

32. Leedle, J.; Greening, R. Postprandial changes in methanogenic and acidogenic bacteria in the rumens of steers fed high-or low-forage diets once daily. Appl. Environ. Microb. 1988, 54, 502-506.

33. Demeyer, D.I.; Locquet, N.; De Graeve, K. Effect van Aminozuren op Hooifermentatie door Pens-en Caecuminhoud van Runderen, 18de Studiedag der Nederlandstalige Voedingsonderzoekers, Gent, 16 April 1993; Ghent University Library: Gent, Belgien, 1993.

34. Sweeten, J.M. Concentrated Animal Feeding Operations in Texas: An Extension, Research and Educational Action Plan for Environmental Quality Management; Texas A\&M University: College Station, TX, USA, 1994.

35. Greening, R.; Leedle, J. Enrichment and isolation of Acetitomaculum ruminis, gen. nov., sp. nov.: Acetogenic bacteria from the bovine rumen. Arch. Microbiol. 1989, 151, 399-406. [CrossRef] [PubMed]

36. Bernalier, A.; Willems, A.; Leclerc, M.; Rochet, V.; Collins, M.D. Ruminococcus hydrogenotrophicus sp. nov., a new $\mathrm{H}_{2} / \mathrm{CO}_{2}$-utilizing acetogenic bacterium isolated from human feces. Arch. Microbiol. 1996, 166, 176-183. [CrossRef] [PubMed]

37. Rieu-Lesme, F.; Morvan, B.; Collins, M.; Fonty, G.; Willems, A. A new $\mathrm{H}_{2} / \mathrm{CO}_{2}$-using acetogenic bacterium from the rumen: Description of Ruminococcus schinkii sp. nov. FEMS Microbiol. Lett. 1996, 140, 281-286. [PubMed] 
38. Lorowitz, W.H.; Bryant, M.P. Peptostreptococcus productus strain that grows rapidly with CO as the energy source. Appl. Environ. Microbiol. 1984, 47, 961-964. [PubMed]

39. Geerligs, G.; Aldrich, H.; Harder, W.; Diekert, G. Isolation and characterization of a carbon monoxide utilizing strain of the acetogen Peptostreptococcus productus. Arch. Microbiol. 1987, 148, 305-313. [CrossRef]

40. Godoy-Vitorino, F.; Goldfarb, K.C.; Karaoz, U.; Leal, S.; Garcia-Amado, M.A.; Hugenholtz, P.; Tringe, S.G.; Brodie, E.L.; Dominguez-Bello, M.G. Comparative analyses of foregut and hindgut bacterial communities in hoatzins and cows. ISME J. 2012, 6, 531-541. [CrossRef] [PubMed]

41. Ley, R.E.; Hamady, M.; Lozupone, C.; Turnbaugh, P.J.; Ramey, R.R.; Bircher, J.S.; Schlegel, M.L.; Tucker, T.A.; Schrenzel, M.D.; Knight, R. Evolution of mammals and their gut microbes. Science 2008, 320, 1647-1651. [CrossRef] [PubMed]

42. Oh, P.L.; Benson, A.K.; Peterson, D.A.; Patil, P.B.; Moriyama, E.N.; Roos, S.; Walter, J. Diversification of the gut symbiont Lactobacillus reuteri as a result of host-driven evolution. ISME J. 2010, 4, 377-387. [CrossRef] [PubMed]

43. Schloss, P.D.; Schubert, A.M.; Zackular, J.P.; Iverson, K.D.; Young, V.B.; Petrosino, J.F. Stabilization of the murine gut microbiome following weaning. Gut Microbes 2012, 3, 383-393. [CrossRef] [PubMed]

44. Godwin, S.; Kang, A.; Gulino, L.-M.; Manefield, M.; Gutierrez-Zamora, M.-L.; Kienzle, M.; Ouwerkerk, D.; Dawson, K.; Klieve, A.V. Investigation of the microbial metabolism of carbon dioxide and hydrogen in the kangaroo foregut by stable isotope probing. ISME J. 2014, 8, 1855-1865. [CrossRef] [PubMed]

45. Breznak, J.A.; Blum, J.S. Mixotrophy in the termite gut acetogen, Sporomusa termitida. Arch. Microbiol. 1991, 156, 105-110. [CrossRef]

46. Muegge, B.D.; Kuczynski, J.; Knights, D.; Clemente, J.C.; González, A.; Fontana, L.; Henrissat, B.; Knight, R.; Gordon, J.I. Diet drives convergence in gut microbiome functions across mammalian phylogeny and within humans. Science 2011, 332, 970-974. [CrossRef] [PubMed]

47. Breznak, J.A.; Kane, M.D. Microbial $\mathrm{H}_{2} / \mathrm{CO}_{2}$ acetogenesis in animal guts: Nature and nutritional significance. FEMS Microbiol. Rev. 1990, 7, 309-313. [CrossRef] [PubMed]

48. Xu, K.; Liu, H.; Du, G.; Chen, J. Real-time PCR assays targeting formyltetrahydrofolate synthetase gene to enumerate acetogens in natural and engineered environments. Anaerobe 2009, 15, 204-213. [CrossRef] [PubMed]

49. Denman, S.E.; Tomkins, N.W.; McSweeney, C.S. Quantitation and diversity analysis of ruminal methanogenic populations in response to the antimethanogenic compound bromochloromethane. FEMS Microbiol. Ecol. 2007, 62, 313-322. [CrossRef] [PubMed]

50. Leaphart, A.B.; Lovell, C.R. Recovery and analysis of formyltetrahydrofolate synthetase gene sequences from natural populations of acetogenic bacteria. Appl. Environ. Microb. 2001, 67, 1392-1395. [CrossRef] [PubMed]

51. Morvan, B.; Bonnemoy, F.; Fonty, G.; Gouet, P. Quantitative determination of $\mathrm{H}_{2}$-utilizing acetogenic and sulfate-reducing bacteria and methanogenic archaea from digestive tract of different mammals. Curr. Microbiol. 1996, 32, 129-133. [CrossRef] [PubMed]

52. Hallenbeck, P.C.; Benemann, J.R. Biological hydrogen production; fundamentals and limiting processes. Int. J. Hydrog. Energy 2002, 27, 1185-1193. [CrossRef]

53. Suzuki, T.; Matsuo, T.; Ohtaguchi, K.; Koide, K. Continuous production of acetic acid from $\mathrm{CO}_{2}$ in repeated-batch cultures using flocculated cells of Acetobacterium woodii. J. Chem. Eng. Jpn. 1993, 26, 459-462. [CrossRef]

54. Balch, W.E.; Schoberth, S.; Tanner, R.S.; Wolfe, R. Acetobacterium, a new genus of hydrogen-oxidizing, carbon dioxide-reducing, anaerobic bacteria. Int. J. Syst. Evol. Microbiol. 1977, 27, 355-361. [CrossRef]

55. Baba, S.; Tashiro, Y.; Shinto, H.; Sonomoto, K. Development of high-speed and highly efficient butanol production systems from butyric acid with high density of living cells of Clostridium saccharoperbutylacetonicum. J. Biotechnol. 2012, 157, 605-612. [CrossRef] [PubMed]

56. Armstrong, D.W.; Yamazaki, H. Natural flavors production-a biotechnological approach. Trends Biotechnol. 1986, 4, 264-268. [CrossRef]

57. Sharpell, F.H.J. Microbial flavors and fragrances. In Comprehensive Biotechnology; Blanch, H.W., Drew, S., Wang, D.I.C., Eds.; Pergamon Press: Oxford, UK, 1985.

58. Playne, M.J. Propionic and butyric acids. In Comprehensive Biotechnology; Moo-Young, M., Ed.; Pergamon Press: Oxford, UK, 1985. 
59. Posey-Dowty, J.D.; Seo, K.S.; Walker, K.R.; Wilson, A.K. Carboxymethylcellulose acetate butyrate in water-based automotive paints. Surf. Coat. Int. B Coat. Trans. 2002, 85, 203-208. [CrossRef]

60. Zidwick, M.J.; Chen, J.S.; Rogers, P. Organic acid and solvent production: Propionic and butyric acids and ethanol. In The Prokaryotes; Springer: Berlin/Heidelberg, Germany, 2013.

61. Álvarez-Chávez, C.R.; Edwards, S.; Moure-Eraso, R.; Geiser, K. Sustainability of bio-based plastics: General comparative analysis and recommendations for improvement. J. Clean. Prod. 2012, 23, 47-56. [CrossRef]

62. Gonzalez-Garcia, R.A.; McCubbin, T.; Navone, L.; Stowers, C.; Nielsen, L.K.; Marcellin, E. Microbial propionic acid production. Fermentation 2017, 3, 21. [CrossRef]

63. Worden, R.M.; Grethlein, A.J.; Zeikus, J.G.; Datta, D.R. Butyrate production from carbon monoxide by Butyribacterium methylotrophicum. Appl. Biochem. Biotechnol. 1989, 20-21, 687-698. [CrossRef]

64. Denman, S.E.; McSweeney, C.S. Development of a real-time PCR assay for monitoring anaerobic fungal and cellulolytic bacterial populations within the rumen. FEMS Microbiol. Ecol. 2006, 58, 572-582. [CrossRef] [PubMed]

65. Yang, C.L.; Guan, L.L.; Liu, J.X.; Wang, J.K. Rumen fermentation and acetogen population changes in response to an exogenous acetogen TWA4 strain and Saccharomyces cerevisiae fermentation product. J. Zhejiang Univ. Sci. B 2015, 16, 709-719. [CrossRef] [PubMed]

66. Tamura, K.; Dudley, J.; Nei, M.; Kumar, S. MEGA4: Molecular evolutionary genetics analysis (MEGA) software version 4.0. Mol. Biol. Evol. 2007, 24, 1596-1599. [CrossRef] [PubMed]

67. Gasteiger, E.; Gattiker, A.; Hoogland, C.; Ivanyi, I.; Appel, R.D.; Bairoch, A. ExPASy: The proteomics server for in-depth protein knowledge and analysis. Nucl. Acids Res. 2003, 31, 3784-3788. [CrossRef] [PubMed]

68. Li, W.; Godzik, A. Cd-hit: A fast program for clustering and comparing large sets of protein or nucleotide sequences. Bioinformatics 2006, 22, 1658-1659. [CrossRef] [PubMed]

69. McMurdie, P.J.; Holmes, S. Phyloseq: An R package for reproducible interactive analysis and graphics of microbiome census data. PLoS ONE 2013, 22. [CrossRef] [PubMed]

70. Anders, S.; Huber, W. Differential expression analysis for sequence count data. Genome Biol. $2010,11$. [CrossRef] [PubMed]

71. Wickham, H. ggplot2: Elegant Graphics for Data Analysis; Springer Science \& Business Media: Berlin, Deutschland, 2009.

72. Warnes, G.R.; Bolker, B.; Bonebakker, L.; Gentleman, R.; Huber, W.; Liaw, A.; Lumley, T.; Mächler, M.; Magnusson, A.; Möller, S. gplots: Various R Programming Tools for Plotting Data. 2009. Available online: https:/ /www.researchgate. net/publication/303186599_gplots_Various_R_programming_tools_for_plottingdata (accessed on 6 June 2018).

73. Stamatakis, A. RAxML-VI-HPC: Maximum likelihood-based phylogenetic analyses with thousands of taxa and mixed models. Bioinformatics 2006, 22, 2688-2690. [CrossRef] [PubMed]

74. Ludwig, W.; Strunk, O.; Westram, R.; Richter, L.; Meier, H.; Buchner, A.; Lai, T.; Steppi, S.; Jobb, G.; Förster, W.; et al. ARB: A software environment for sequence data. Nucl. Acids Res. 2004, 32, 1363-1371. [CrossRef] [PubMed]

75. McSweeney, C.S.; Denman, S.E.; Mackie, R.I. Rumen Bacteria. In Methods in Gut Microbial Ecology for Ruminants; Makkar, H.P.S., McSweeney, C.S., Eds.; Springer: Dordrecht, The Netherlands, 2005.

76. Hungate, R.E. A roll tube method for cultivation of strict anaerobes. In Methods in Microbiology; Norris, J.R., Ribbons, D.W., Eds.; Academic Press: London, UK, 1969.

77. Gagen, E.J.; Wang, J.; Padmanabha, J.; Liu, J.; de Carvalho, I.P.; Liu, J.; Webb, R.I.; Al Jassim, R.; Morrison, M.; Denman, S.E. Investigation of a new acetogen isolated from an enrichment of the tammar wallaby forestomach. BMC Microbiol. 2014, 14. [CrossRef] [PubMed]

(C) 2018 by the author. Licensee MDPI, Basel, Switzerland. This article is an open access article distributed under the terms and conditions of the Creative Commons Attribution (CC BY) license (http:/ / creativecommons.org/licenses/by/4.0/). 